\title{
REŽIMY SPRÁVNÍHO PRÁVA
}

\author{
JOSEF STAŠA
}

\begin{abstract}
Administrative Law Regimes
The administrative law regime means a typical legal construction, which expresses the way of connecting an administrative law norm with this norm anticipated administrative law relationship through a certain legally significant fact. From the point of view of public administration addressees, it is appropriate to differ regimes of granting rights and regimes of imposing obligations primarily. Many regimes have a superstructure (secondary) nature, they assume the earlier existence of other (primary) rights and obligations. In addition to unilateral regimes, there are also bilateral or multilateral regimes of administrative law, which are an expression of cooperation in connection with the performance of public administration. From the point of view of public administration bodies, it is possible to distinguish several (administrative) regimes of exercise of their competence (powers). A kind of complement is the regimes that determine the boundaries of administrative regulation (between public law and civil law; between national law and European law). The application of some regimes or their combination typically results in the general administrative law concepts (= the tangles of administrative law norms cemented by the need and effort to solve certain idealized situations, deprived of their specific content). The research of administrative law regimes may perhaps contribute to a more plastic and systematic doctrinal characterization of material administrative law.
\end{abstract}

Keywords: administrative law; administrative law norm; legally significant fact; administrative law relationship; administrative law regime; general administrative law concept

Klíčová slova: správní právo; norma správního práva; právně významná skutečnost; vztah správního práva; režim správního práva; obecná figura správního práva

DOI: $10.14712 / 23366478.2021 .38$

Tento př́spěvek zčásti využívá textu o režimech formování vztahů správního práva, který byl publikován před více než 10 lety, a navazuje na některé úvahy v něm obsažené, popř́padě je koriguje. ${ }^{1}$

1 STAŠA, J. K problematice administrativněprávních režimů formování právních vztahů. In: KADEČKA, S. (ed.). Pocta Petru Průchovi. Praha: Vysoká škola aplikovaného práva, 2009, s. 81-91. 
Následující výklad je pouze obrysovou charakteristikou problematiky režimů správního práva, nezaměřuje se na žádnou jeho podoblast či na některý úsek veřejné správy a s výjimkou uvedených př́kladů odhlíží od terminologie pozitivního práva.

\section{PŘED ZÁVORKOU}

Správní právo představuje část právního řádu² orientovanou v podústavní rovině na uspořádání a působení veřejné správy a na její kontrolu zvnějšku, popřípadě na některé další souvislosti či paralely veřejné správy. ${ }^{3}$

Správní působení lze vymezit v užším slova smyslu jako efektivní působení (= správní činnost), nebo v širším slova smyslu, zahrnujícím kromě efektivního působení i působení potenciální/latentní. Alternativním př́istupem by bylo ztotožnit správní působení se správní činností a „zbytek“ zahrnout do předmětu správního práva s využitím pravidla souvislosti.

Typické správní působení je reflektováno právním vztahem mezi nositelem veřejné správy „Zastupovaným“ některým jeho vykonavatelem na straně jedné a osobou, vůči níž toto působení směřuje, označovanou jako adresát veřejné správy. Mnohost nositelů veřejné správy vytváří prostor pro právní vztahy mezi nimi. Vedle organizačních vztahů existují, resp. mohou existovat právní vztahy i v rámci každého jednoho nositele veřejné správy. Vcelku výjimečným doplňkem jsou vztahy správního práva mezi adresáty veřejné správy.

Výchozím předpokladem všech výše uvedených skupin ${ }^{4}$ právních vztahů (= vztahů správního práva) jsou normy správního práva. K aktivaci právního vztahu, jakož i k jeho prŕípadnému pozdějšímu vývoji, je dále nezbytná existence určité právně významné skutečnosti, ${ }^{5}$ resp. kombinace určitých právně významných skutečností. Onou právní skutečností může být, vyjádřeno zobecněně, explicitní projev vůle (nositele/vykonavatele veřejné moci včetně vrchnostenské veřejné správy, nositele/vykona-

2 Obecnější označení se pro účely dalšího výkladu zdá být vhodnější než pojem „odvětvi““ (či pojmy podobné). Mezi různými částmi (podmnožinami) právního řádu existují průniky. „Odvětvový“ př́istup dospívá v souvislosti s diferenciací právního řádu od prvotního (chudšího/jednoduššího) členění k bohatšímu/složitějšímu. Správní právo se tak vlastně již velice dlouhou dobu drolí. Srov. na př́ikladu finančního práva, práva sociálního zabezpečení nebo práva životního prostředí. A další následují nebo budou následovat. Problematika režimů a figur je ale pro „zbylé“ správní právo a pro „renegáty“ společná.

3 Dle schématu „typické - související - podobné“. Inspirativní je použití pravidla podobnosti a souvislosti při vymezování předmětu právní regulace, potažmo částí právního řádu (srov. KNAPP, V. Předmět a systém československého socialistického práva občanského. Praha: Nakladatelství Československé akademie věd, 1959, s. 77 nebo 153). Jde ovšem rovněž o to, co je pro uplatnění tohoto pravidla limitující, resp. od čeho limity odvíjet, což může být ve vztahu $\mathrm{k}$ jednotlivým částem právního řádu zejména vzhledem $\mathrm{k}$ možným překryvům rozdílné. Ve vztahu ke správnímu právu to bude výkon veřejné správy (nikoli relace mezi subjekty právních vztahů, jak by mohlo vyplývat z textu na s. 154 cit. díla).

4 Viz VOPÁLKA, V. [úprava STAŠA, J.]. Vztahy správního práva. In: HENDRYCH, D. a kol. Správní právo: obecná ćást. 9. vyd. Praha: C. H. Beck, 2016, s. 53-54.

5 Ve své době viz GAŠPAR, M. Administrativnoprávne normy a administrativnoprávne vztahy. In: GAŠPAR, M. a kol. Československé správne právo. Bratislava: Obzor, 1973, s. 140; nebo DELONG, V. Administrativněprávní vztahy. In: LUKEŠ, Z. a kol. Československé správní právo: obecná část. Praha: Panorama, 1981, s. 56; podrobněji KOPECKÝ, M. Správní právo: obecná ćást. Praha: C. H. Beck, 2019, s. $38-40$. 
vatele nevrchnostenské veřejné správy, adresáta veřejné správy), neformální/faktické chování (nositele/vykonavatele veřejné správy, adresáta veřejné správy) nebo na ničí vůli nezávislá událost. Explicitní projev vůle nebo neformální/faktické chování mohou být jak secundum et intra legem, popř́padě extra legem, tak contra legem, poprípadě in fraudem legis. Explicitní projev vůle může mít povahu veřejnoprávního úkonu i soukromoprávního jednání, rovněž neformální/faktické chování může vyvěrat z poměrů veřejného i soukromého práva. ${ }^{6}$

\section{REŽIMY SPRÁVNÍHO PRÁVA}

Režimem správního práva (dále též pouze „režim“) je v dalším textu označována typická právní konstrukce, která vyjadřuje způsob propojení normy správního práva s touto normou anticipovaným vztahem správního práva prostřednictvím určité právně významné skutečnosti.

Při vymezování jednotlivých režimů se nabízí využít více hledisek. Spíše heuristicky (než systematicky) lze vzít v potaz ${ }^{7}$ alespoň

- potřebnou razantnost právní regulace, která by měla být odvozena od významu/závažnosti touto regulací chráněného zájmu,

- zda je smyslem dané regulace umožnit určité chování (= v obsahu danou normou správního práva anticipovaného právního vztahu dominuje oprávnění), nebo k určitému chování zavázat ( $=\mathrm{v}$ jeho obsahu dominuje povinnost), popř́ípadě zda jde o kombinaci toho a onoho a jaká je v př́padě kombinace skladba/vazebnost oprávnění a povinností,

- zda je smyslem regulace formovat vztahy správního práva, nebo odstran̆ovat pochybnosti či řešit spory ohledně jejich existence/parametrů,

- jaký je způsob dané regulace (vyjádření v podobě prríkazů, zákazů, popřípadě dovolení; formulace oprávnění a povinností),

- zda je, či není v daném př́ípadě zapotřebí interakce s vykonavatelem (vykonavateli) veřejné správy, či nikoli,

- zda se potřebná/předepsaná interakce s vykonavatelem (vykonavateli) veřejné správy v daném př́padě odehrává výlučně na naší národní úrovni, nebo i na evropské úrovni či na národní úrovni jiných států,

6 Soukromoprávní skutečnost jako předpoklad vzniku vztahu správního práva (= veřejnoprávního vztahu) nutno odlišit od soukromoprávní regulace správní činnosti v rámci výkonu veřejné správy (výsostné i nevýsostné). Různé pohledy viz STAŠA, J. Vztah mezi povahou a důsledky správní činnosti z hlediska právního dualismu. In: HANDRLICA, J. (ed.). Verejné právo a právo soukromé: aktuálni tendence a výzvy veřejnoprávni úpravy plynoucí z problematiky právního dualismu. Praha: Univerzita Karlova v Praze, Právnická fakulta, 2014, s. 95-110; HANDLICA, J. Jednání soukromoprávních subjektů s důsledky ve sféře veřejného práva. In: HANDRLICA, J. (ed.). Veřejné právo a právo soukromé: aktuální tendence a výzvy veřejnoprávní úpravy plynoucí z problematiky právního dualismu. Praha: Univerzita Karlova v Praze, Právnická fakulta, 2014, s. 111-128; SVOBODA, P. Privatizace veřejné moci v České republice. In: HANDRLICA, J. (ed.). Veřejné právo a právo soukromé: aktuální tendence a výzvy veřejnoprávní úpravy plynoucí z problematiky právního dualismu. Praha: Univerzita Karlova v Praze, Právnická fakulta, 2014, s. 129-134.

7 S možnými překryvy. 
- čí projev vůle nebo čí neformální/faktické chování iniciuje („spouští“) daný mechanismus regulace a čí projev vůle nebo čí neformální/faktické chování [včetně důsledků př́ípadné(ho) nečinnosti/nekonání] bezprostředně/finálně vyvolává danou normou (danými normami) správního práva předvídané účinky,

- zda daná regulace počítá s řešením konfliktu zájmů, nebo zda je určena pro konsensuální prostředí a počítá se shodnými projevy vưle nebo se souladným neformálním/ faktickým chováním více participantů předvídaného právního vztahu,

- zda má daný mechanismus regulace výlučně hmotněprávní povahu, nebo je nutně (vždy, popř́ípadě za určitých okolností) spojen s určitým formálním postupem (právním procesem),

- zda má daná regulace povahu kategorickou, či nikoli, popř́padě jakou míru volnosti poskytuje subjektům anticipovaného právního vztahu při utváŕení jeho obsahu (u vztahů mezi nositelem veřejné správy a adresátem veřejné správy jde na straně vykonavatele veřejné správy o ,prostor“ při vyhodnocování určité situace, ${ }^{8} \mathrm{v}$ souvislosti s výkladem neurčitých právních pojmů nebo v rámci uplatňování diskrece a na straně adresáta o míru konkrétnosti představy o „chování“9 vykonavatele založené na legitimním očekávání),

- zda daná regulace obstojí jako samostatná, nebo zda předpokládá existenci jiné (= primární) regulace, kterou (jako nadstavbová modifikující regulace) dotvárí, nebo na niž a/nebo na jejíž poruchu (jako nadstavbová sekundární regulace) navazuje.

\section{K vymezení režimů správního práva: ${ }^{10}$}

Z pohledu adresáta veřejné správy se nabízí vyjít ze smyslu dané regulace a rozlišovat na jedné straně režimy týkající se (v prvním plánu) ${ }^{11}$ přiznávání oprávnění (poněkud krkolomně řečeno „oprávněnostní“) a režimy týkající se (v prvním plánu) ${ }^{12}$ ukládání povinností (zde méně krkolomně ,povinnostní“, pro adresáta ,zatěžujícíc). Řada režimů má nadstavbovou (sekundární) povahu, předpokládá dř́vější existenci jiných (primárních) práv a povinností. Vedle jednostranných režimů existují i dvoustranné/vícestranné režimy správního práva, které jsou výrazem kooperace ve veřejné správě, resp. v souvislosti s výkonem veřejné správy. $Z$ pohledu nositele/vykonavatele veřejné správy jde o (správněprávní) režimy výkonu působnosti a pravomoci. Jakýsi doplněk představují režimy určující hranice správněprávní regulace (= „rozhraničující“).

\footnotetext{
8 Předpokladů uskutečnění správního úkonu a/nebo podkladů pro formulaci jeho obsahu.

9 Př́kladmo otázka (ne)nárokovosti, otázka modifikace obsahu požadavku adresáta z moci úřední.

10 Jinak (a zřejmě na jedné straně méně přehledně a na druhé straně poněkud strnule) ve stati zmíněné v poznámce č. 1. Základní členění režimů tam vycházelo ze schématu (i) 11 jednostranných režimů vzniku subjektivních práv, (ii) 8 jednostranných režimů vzniku povinností, (iii) 3 dvoustranné nebo vícestranné režimy vzniku subjektivních práv/povinností, (iv) 3 nadstavbové režimy a (v) 5 hraničních režimů. Heterogenní a zvnějšku nejméně čitelná poslední skupina režimů zohledňovala regulaci důsledků nečinnosti veřejné správy, regulace umožňující odchylné než „standardní“, popřípadě předepsané chování participantů právních vztahů, jakož i regulaci rozhraní mezi vztahy vně veřejné správy a vztahy v rámci její organizace.

11 Obsah anticipovaného právního vztahu se nemusí vyčerpávat oprávněními, nicméně ta dominují.

12 Obsah anticipovaného právního vztahu se nemusí vyčerpávat povinnostmi, nicméně ty dominují.
} 


\subsection{K REŽIMƯM TÝKAJÍCÍM SE PŘIZNÁVÁNÍ OPRÁVNĚNÍ}

O oprávnění se zásadně uchází, popřípadě možnost chovat se určitým způsobem využívá ze své vůle adresát veřejné správy. Odtud se v podstatě v závislosti na razantnosti právní regulace odvíjí základní řada těchto režimů tvořená volným režimem, oznamovacími režimy, reaktivními režimy, schvalovacími režimy a povolovacími režimy.

Ve volném režimu může adresát veřejné správy bez dalšího vykonávat činnost zákonem dovolenou (= nezakázanou). ${ }^{13}$ Zmiňuje-li zákon nějakou takovou činnost výslovně, činí tak proto, aby ji odlišil od činnosti tímto zákonem přísněji (razantněji) regulované (může jít jak o pouhé negativní vymezení, ${ }^{14}$ tak o robustnější pozitivní úpravu ${ }^{15}$ ). Některé činnosti v rámci volného režimu lze vykonávat pouze za stanovených předpokladů týkajících se zejména toho, kdo je vykonává ${ }^{16}$ (vykonává-li takovou činnost někdo, kdo tyto předpoklady nesplňuje, jde o nezákonné chování), ${ }^{17}$ nebo okolností, za nichž jsou vykonávány. ${ }^{18}$ Splnění některých předpokladů je zřejmé, splnění jiných předpokladů si posuzuje sám adresát, který ovšem rovněž nese riziko chybného posouzení. Pro výkon některých činností v rámci volného režimu jsou stanovena závazná pravidla. ${ }^{19}$ Volný režim nepředpokládá žádnou interakci adresáta s některým vykonavatelem veřejné správy. Modifikaci může přinést požadavek adresáta na poskytnutí předběžné informace, ${ }^{20}$ která by měla postavit adresátovi najisto, zda/že se jím zamýšlená činnost může uskutečnit ve volném režimu. Platí, že i činnost v rámci volného režimu může podléhat, resp. podléhá některým nadstavbovým režimům. ${ }^{21}$

13 Dovoleno je, co není zákonem zakázáno (čl. 2 odst. 4 Ústavy České republiky, čl. 2 odst. 3 Listiny základních práv a svobod). Mezi obecné principy patří zákaz obcházení zákona a zákaz zneužití práva.

14 Srov. § 3 odst. 3 písm. f) zákona č. 455/1991 Sb., o živnostenském podnikání (živnostenský zákon), ve znění pozdějších předpisů (živností není prodej nezpracovaných rostlinných a živočišných výrobků z vlastní drobné pěstitelské a chovatelské činnosti fyzickými osobami); nebo $§ 79$ odst. 2 a 3 a $§ 80$ odst. 3 až 5 zákona č. 183/2006 Sb., o územním plánování a stavebním řádu (stavební zákon), ve znění pozdějších předpisů (pro umístění záměrů tam uvedených se nevyžaduje ani územní souhlas), jakož i § 103 cit. stavebního zákona (pro provedení tam uvedených stavebních záměrů se nevyžaduje ani ohlášení stavebnímu úřadu).

15 Př́íkladem je obecné užívání pozemních komunikací (§ 19 a násl. zákona č. 13/1997 Sb., o pozemních komunikacích, ve znění pozdějších předpisů).

16 Ve vztahu k obecnému užívání pozemních komunikaci srov. požadavky na účastníky provozu podle $\$ 3$ zákona č. 361/2000 Sb., o provozu na pozemních komunikacích a o změnách některých zákonů (zákon o silničním provozu), v platném znění; k řidičskému oprávnění viz $\S 80$ a násl. cit zákona o silničním provozu.

17 V návaznosti na absenci předepsaného řidičského oprávnění viz § $125 \mathrm{c}$ odst. 1 písm. e) bod 1 cit. zákona o silničním provozu.

18 U obecného užívání pozemních komunikací může jít o okolnosti na straně uživatele i na straně užívaného statku. Okolnosti na straně uživatele se týkají požadavků na provozovaná silniční vozidla [§ 36 a násl. zákona č. 56/2001 Sb., o podmínkách provozu vozidel na pozemních komunikacích a o změně zákona č. 168/1999 Sb., o pojištění odpovědnosti za škodu způsobenou provozem vozidla a o změně některých souvisejících zákonů (zákon o pojištění odpovědnosti z provozu vozidla), ve znění zákona č. 307/1999 Sb., ve znění pozdějších předpisů]. Okolností na straně uživaného statku je sjízdnost/schůdnost pozemní komunikace (§ 26 a násl. cit zákona o pozemních komunikacích).

19 Především ve vztahu k obecnému užívání pozemních komunikací viz $§ 4, \S 10$ odst. 3 , § 11 a násl. a § 69 a násl. cit. zákona o silničním provozu, jakož i prováděcí předpisy k tomuto zákonu.

20 Obecně viz § 139 zákona č. 500/2004 Sb., správní řád. Konkrétně pak § 21 cit. stavebního zákona.

21 Výkonu dozorčí činnosti a uplatňování správní odpovědnosti. 
Ve vztahu k volnému režimu zůstává nezodpovězena otázka právní povahy (kvality) činnosti uskutečňované $v$ jeho rámci. Tato otázka ještě nepadla obecně (vůči všem takovým činnostem), ale týkala se dosud pouze obecného užívání veřejných (veřejně prrístupných) statků. ${ }^{22}$ Možná, že lze uvažovat o jejím zobecnění. ${ }^{23}$ Jde u této činnosti o výkon/konzumaci veřejného subjektivního práva na straně jedné, či o chování v mezích obecné volnosti/svobody, popřípadě o prosté využití možnosti poskytnuté objektivním právem na straně druhé? Argumenty bylo/je možné snášet na obě strany. ${ }^{24}$ Praktický význam řešení této otázky vyvstane až pro případ hledání právní ochrany proti tomu, kdo uskutečňování předmětné činnosti klade překážky. Rozumné je přiklonit se k závěru, že ono veřejné subjektivní právo existuje. Zužujícím řešením by bylo omezit se na formulaci veřejného subjektivního práva na ochranu před neoprávněnými zásahy do činnosti uskutečňované $v$ rámci volného režimu. Alternativou by bylo balancovat na nepř́líš jisté hranici mezi (neexistujícím) veřejným subjektivním právem a (existujícím) dotčením právní sféry adresáta. ${ }^{25}$

Pro skupinu oznamovacích režimů je př́iznačné, že oprávnění vzniká přímo v důsledku projevu vůle adresáta (= oznámení př́íslušnému vykonavateli veřejné správy). Oznamovatel musí splňovat stanovené (hmotněprávní) předpoklady a oznámení musí mít stanovené náležitosti (včetně př́ípadných př́loh, jimiž se splnění stanovených předpokladů dokládá).

V základním módu vzniká oprávnění ex lege dojitím oznámení př́slušnému vykonavateli veřejné správy. ${ }^{26}$ Úřední kontrola splnění stanovených hmotněprávních předpokladů zde probíhá po vzniku oprávnění. Vzniklé oprávnění bude zaevidováno a jeho existence může/musí být osvědčena.

Nesplňuje-li oznamovatel stanovené předpoklady, oprávnění nevznikne, resp. nevzniklo. Tuto skutečnost z moci úřední autoritativně deklaruje př́slušný vykonavatel

22 Týkala se obecného uživání veřejných statků. V současné judikatuře ji lze vysledovat ve vztahu k již zmíněnému obecnému užívání pozemních komunikací.

${ }^{23} \mathrm{~K}$ opačnému závěru může vést zdůrazňování jedinečnosti smyslu regulace užívání veřejných (veřejně přístupných) statků; do popředí zde vystupuje uspokojování společenské potřeby jejich užívání.

24 Historicky starší je názor o neexistenci veřejného subjektivního práva, založený na úvahách o povaze veřejných statků (veřejných věcí, veřejného vlastnictví). K právu na uživání zřízené/trvající veřejné cesty ex titulo usus publici viz již HOETZEL, J. Československé správni právo: část všeobecná. Praha: Melantrich, 1934, s. 281-282. Dnes lze dodat, že ve prospěch názoru, že jde o veřejné subjektivní právo, svědčí pochybnost o rozdílné věcné povaze méně přísně regulované činnosti a přísněji regulované činnosti (u níž pochybnost o kvalitě oprávnění coby veřejného subjektivního práva neexistuje), a to zejména $v$ prípadech, kdy je rozhraní mezi nimi určeno výhradně kvantitativními parametry. Dosavadní judikatura nevede ke spolehlivým závěrům; ve volnější souvislosti lze na jedné straně poukázat na rozsudek Nejvyššího správního soudu ze dne 15. listopadu 2007, č. j. 6 Ans 2/2007-128 (přiznání možnosti vést řízení o žádosti o odstranění pevné překážky umístěné na veřejně př́istupné účelové komunikaci), na druhé straně pak na rozsudek Nejvyššího správního soudu ze dne 30. března 2016, č. j. 10 As 264/2015-46 (o úzkém okruhu účastníků správního řízení o omezení obecného užívání veřejně př́stupné účelové komunikace uzavírkami a objižd'kami; vzhledem ke skutečnosti, že rozhodnutí o uzavírce a objižd'ce doprovází stanovení přechodné úpravy pravidel silničního provozu, viz k domyšlení celkového obrazu i dřívější rozsudek Nejvyššího správního soudu ze dne 24. ř́ína 2013, č. j. 4 Aos 3/2013-33); rozpory jsou patrné.

25 Volně inspirováno úvahami obsaženými v odůvodnění usnesení rozšířeného senátu Nejvyššího správního soudu ze dne 21. ř́ijna 2008, č. j. 8 As 47/2005-86.

26 Př́kladem z pozitivního práva je ohlášení živnosti; viz $\S 9$ písm. a), § 10 odst. 1 písm. a) a $\S 45$ a násl. cit. živnostenského zákona. O vhodnosti formulace ustanovení $§ 45$ odst. 1 lze diskutovat. 
veřejné správy. ${ }^{27}$ Obdobné důsledky jako nesplnění hmotněprávních předpokladů pro vznik oprávnění má neodstranění vad oznámení (na základě výzvy, popř́ípadě výzev vykonavatele veřejné správy). ${ }^{28} \mathrm{~V}$ obou př́padech vzniká „namísto“ oznamovatelem zamýšleného hmotněprávního vztahu posléze ${ }^{29}$ pouze vztah procesní. Je otázkou, zda vůbec, popř́ípadě do kdy je relevantní eventuální odstranění nedostatku předpokladů nebo oznámení až poté, co př́islušný vykonavatel veřejné správy zahájil správní řízení o tom, že oprávnění oznámením nevzniklo.

Ve srovnání s uvedeným je méně razantní požadavek následného/dodatečného oznámení, které je předpokladem trvání předmětného oprávnění. Naopak razantnější je požadavek předběžného oznámení, kdy oprávnění vznikne (až) po uplynutí stanovené doby a za předpokladu, že v jejím průběhu nedojde ke zvratu v důsledku projevu vůle vykonavatele veřejné správy (může jít o konstatování, že nejsou splněny stanovené předpoklady vzniku oprávnění, popřípadě o vydání určitého zákazu ${ }^{30}$ ).

Reaktivní režimy tvoří jakýsi přechod mezi ohlašovacími režimy a schvalovacími režimy. Po jejich bližším srovnání se naskýtá pochybnost ohledně toho, zda skutečně jde o rovnocennou/samostatnou kategorii. Na rozdíl od ohlašovacích režimů zde oprávnění vzniká až poté, co př́islušný vykonavatel veřejné správy učiní předepsaný úkon. $\mathrm{Na}$ rozdíl od schvalovacích režimů není onen úkon vykonavatele veřejné správy úkonem regulativní povahy (jde o neregulativní evidenční/registrační úkon), přičemž oprávnění vzniká ex lege (nikoli ex actu).

Ohlašovacímu režimu je blízká situace, kdy oprávnění vzniká (až) úředním potvrzením skutečnosti, že projev vůle adresáta došel př́islušnému vykonavateli veřejné správy (= prostý mód reaktivních režimů).

Schvalovacímu režimu je blízká situace, která ke vzniku oprávnění vyžaduje úřední úkon, jehož obsahem je (konec konců) osvědčení, poprrípadě autoritativní zjišš̌ní a konstatování skutečnosti, že jsou splněny předpoklady vzniku oprávnění (registrace). Pro registraci může (ale nemusí) být předepsána procesní forma. $V$ př́ipadě, že je předepsána, předchází vznik procesního vztahu (ten vzniká podáním návrhu na registraci) vzniku vztahu hmotněprávního, $\mathrm{k}$ němuž dochází až nástupem právních účinků registrace. Není-li předepsána, je pro př́ípad neprovedení registrace zahajováno rízení z moci úřední (podobně jako u ohlašovacího režimu). Registrační mód reaktivních režimů (označovaný též jako registrační režim) se může týkat legální aprobace určitých dokumentů, ${ }^{31}$ ale i vzniku právních subjektů..$^{32}$ Pro případ nečinnosti př́islušného vykonavatele veřejné správy může být modifikován fikcí/domněnkou registrace. ${ }^{33}$ Může být výrazem právně politického postoje zákonodárce privilegovat určité veřejné subjektivní

27 Srov. $\$ 47$ odst. 6 cit. živnostenského zákona.

28 Srov. $\$ 47$ odst. 5 cit. živnostenského zákona.

29 Oznámením o zahájení řízení.

30 K naposled uvedenému viz k 1. lednu 2018 zrušený § 120 cit. stavebního zákona (oznámení záměru započít s užíváním dokončené stavby).

31 Viz § 36 a $\$ 41$ zákona č. 111/1998 Sb., o vysokých školách a o změně a doplnění dalších zákonů (zákon o vysokých školách), ve znění pozdějších předpisů; registrace je předpokladem platnosti tzv. vnitřních předpisů vysokých škol.

32 Viz $\S 2$ odst. 1 a $\S 6$ odst. 1 zákona č. 424/1991 Sb., o sdružování v politických stranách a v politických hnutích, ve znění pozdějších předpisů.

33 Viz $§ 8$ odst. 4 cit. zákona o sdružování v politických stranách a v politických hnutích. 
právo (zdůraznit jeho nepodrobenost razantněǰš́mu režimu). ${ }^{34}$ Reaktivní režimy nejsou vhodné pro řešení situací, kdy se vznik/výkon oprávnění může přímo dotýkat právních poměrů třetích osob.

Co do razantnosti regulace následuje skupina schvalovacích režimů. Obrat oproti předchozím režimům spočívá $\mathrm{v}$ tom, že oprávnění, o něž se adresát uchází, vzniká až $\mathrm{v}$ důsledku projevu vůle př́slušného vykonavatele veřejné správy, z jeho úkonu, který má povahu konstitutivního správního aktu. Jde tedy o předběžné schvalování.

V základním módu př́islušný vykonavatel veřejné správy rozhoduje o žádosti adresáta a pozitivním rozhodnutím je udělení souhlasu. Vzniku hmotněprávního vztahu předchází vztah procesní (dojitím žádosti př́slušnému vykonavateli veřejné správy je zahájeno správní rízení). Oprávnění vzniká vykonatelností pozitivního rozhodnutí, popř́padě, v závislosti na obsahu žádosti, později. Splňuje-li žadatel stanovené (hmotněprávní) předpoklady a je-li žádost bezvadná, poprrípadě odstranil-li žadatel vady imperfektní žádosti, je na schválení právní nárok. ${ }^{35}$ Obsahem schválení je „prostý، souhlas (rozhodnutí nemůže obsahovat žádná vedlejší ustanovení). Negativním výsledkem je zamítnutí žádosti (z prríčin hmotněprávních), nebo zastavení řízení (z príčin procesních).

Ve zjednodušeném módu nejde o řízení o žádosti adresáta. ${ }^{36}$ Použití tohoto módu je vhodné, jestliže se vznik/výkon oprávnění nemůže týkat třetích osob, nebo jestliže možnému vzniku oprávnění svědčí konsensuální prostř̌edí, ${ }^{37}$ popřípadě i v jiných případech, jde-li pouze o „bagatelní záležitost“. Specifické je zde negativní vyústění (není co zamítat), řešením může být přikázání věci do povolovacího (tedy př́snějšího) režimu. Alternativní řešení může být podobné jako u ohlašovacích režimů či u registračního režimu (zahájení rízení z moci úřední). Podle okolností a v závislosti na vůli adresáta lze projednání věci v rámci schvalovacích režimů (prakticky právě zejména ve zjednodušeném módu) ,udržet“ předložením nového (korigovaného) záměru. ${ }^{38}$

Výraznější modifikaci představuje následné schvalování, které lze chápat nejspíše bud' jako předpoklad nástupu účinků již učiněného projevu vůle vykonavatele veřejné správy sledujícího vznik oprávnění k ,dotvrzení“ jeho vzniku (v rámci nějaké složitější/ složené právní konstrukce), nebo jako souhlas s trváním již vzniklého ${ }^{39}$ (na základě uplatnění méně razantního režimu) oprávnění (v př́ípadě neschválení by již vzniklé oprávnění mělo zaniknout a další postup by se měl odvíjet od skutečnosti, zda adresát oprávnění nabyl v dobré víre, či nikoli).

34 Srov. $§ 1$ odst. 2 již zrušeného zákona č. 83/1990 Sb., o sdružování občanů.

$35 \mathrm{~V}$ případě neexistence právního nároku by mělo jít o obdobu koncesního režimu (jeden z módů povolovacích režimů).

36 Podání (,,výchozi““ úkon) adresáta není návrhem na zahájení správního řizení. Některá jeho tradiční označení v pozitivním právu („oznámeni““, „ohlášeni““) mohou svádět k nesprávnému zařazení zjednodušeného módu mezi režimy oznamovací.

37 Srov. požadavek vyplývající z $§ 96$ odst. 3 písm. d) a/nebo z § 105 odst. 2 písm. f) cit. stavebního zákona.

38 Korigovaný záměr může ,vstřebat“ reglementy, které by v rámci povolovacího režimu byly uloženy jako vedlejší ustanovení.

39 Podobné řešení viz v $§ 118$ odst. 7 a $\$ 121$ odst. 1 cit. stavebního zákona (aprobace nepodstatných odchylek skutečného provedení stavby od ověřené dokumentace stavby při vydání kolaudačního souhlasu). 
Pro př́ípad nečinnosti př́slušného vykonavatele veřejné správy je i u schvalovacích režimů možné ,zpestření“ v podobě fikce/domněnky souhlasu, ${ }^{40}$ jejímuž nástupu lze modelově čelit, kromě jiného, vydáním zákazu činnosti ${ }^{41}$, v níž by spočíval výkon oprávnění, resp. souhlasu uděleného tacite (pokud nebyly splněny předpoklady pro udělení souhlasu, mělo by nejspíše následovat rozhodnutí o tom, že oprávnění zaniká) ${ }^{42}$.

Nejpřísnější regulaci vyjadřují povolovací režimy. Na rozdíl od schvalovacích režimů může/musí př́slušný vykonavatel veřejné správy na základě zákona vlastním projevem limitovat obsah správním aktem udělovaného oprávnění. Děje se tak v podobě vedlejších ustanovení onoho správního aktu. ${ }^{43}$ Pokud je obsah projevu vůle vykonavatele veřejné správy kategoricky určen a nemůže se nijak lišit $\mathrm{v}$ závislosti na okolnostech konkrétního př́ípadu, bylo by př́hodnější řešit takovou situaci předepsáním schvalovacího režimu. Racionálně předepsaný povolovací režim tedy předpokládá jistou dávku volnosti, kterou má daný vykonavatel při uplatňování své pravomoci.

Klasický mód povolovacích režimů (klasický povolovací režim) zakládá tomu, kdo splňuje stanovené (hmotněprávní) předpoklady a podá perfektní žádost, právní nárok na vydání povolení (vyhovění žádosti), ${ }^{44}$ které může obsahovat (na rozdíl od souhlasu) určitá vedlejší ustanovení. Zamítnutí žádosti musí být odůvodněno nesplněním konkrétního hmotněprávního předpokladu vzniku oprávnění.

Jestliže právní nárok na vyhovění žádosti neexistuje (stanoví-li tak zákon, popř́ípadě vyplývá-li to ze zákona), jde o koncesní mód povolovacích režimů (označovaný též jako koncesní režim). ${ }^{45}$ Vydání (udělení) koncese je záležitostí správního uvážení př́íslušného vykonavatele veřejné správy. Zamítnutí žádosti může být odůvodněno konec konců i poukazem na nedostatek (obecné) potřeby udělit oprávnění, resp. další oprávnění, nebo na nedostatku veřejného zájmu na udělení oprávnění, resp. dalšího oprávnění. Diskreční pravomoc ale není v dnešní době neomezená, i pozitivní právo (zákon) stanoví (přinejmenším) obecná hlediska pro její uplatňování. ${ }^{46}$

Rozdíl mezi klasickým povolovacím režimem a koncesním režimem relativizuje i použití vágnějších neurčitých právních pojmů při formulaci předpokladů vzniku oprávnění. ${ }^{47} \mathrm{U}$ obou zmíněných módů povolovacích režimů je obsah správního aktu,

40 Modelový př́klad ve vztahu ke schvalovacímu režimu byl obsažen v původním znění $§ 106$ odst. 1 cit. stavebního zákona (účinném do 31. prosince 2012).

41 Původní znění § 107 odst. 1 cit. stavebního zákona (účinné do 31. prosince 2012).

42 Fakticky na úrovni souhlasu uděleného tacite (s tím, že může jít i o oprávnění, jehož vznik by jinak podléhal povolovacímu režimu) je $§ 28$ zákona č. 222/2009 Sb., o volném pohybu služeb; viz dále jeho $§ 30$ odst. 2.

43 Jde zejména o modus (př́kaz), o podmínku, o časovou doložku, popřípadě o výhradu. V pozitivním právu se často módy označují (doktrinálně vzato nepřesně) jako „podmínky“.

44 Př́ikladem z pozitivního práva je udělení oprávnění provozovat koncesovanou živnost; viz $\S 9$ písm. b), $\S 10$ odst. 1 písm. b) a $\S 50$ a násl. cit. živnostenského zákona. Existence právního nároku nemusí být vyjádřena explicitně. Zároveň jde o dobrý příklad problematického použití termínu ,koncese“; viz $§ 5$ odst. 1 cit. živnostenského zákona (,,povolení“ je v tradiční terminologii z hlediska nárokovosti totiž protikladem „koncese“).

45 Viz $§ 11$ a násl. (a zejména $§ 16$ odst. 4) zákona č. 266/1994 Sb., o dráhách, ve znění pozdějších předpisů (jde o úřední povolení k provozování dráhy). Ani v tomto př́ípadě neodpovídá terminologie platného práva tradici.

46 Viz $§ 2$ cit. správního řádu.

47 Tak díky požadavku průhlednosti a nezávadnosti finančních zdrojů coby předpokladu vydání bankovní licence je zřejmě vznik oprávnění vykonávat činnost banky podroben koncesnímu režimu. Viz $§ 4$ odst. 5 písm. a) zákona č. 21/1992 Sb., o bankách, ve znění pozdějších předpisů. 
jímž bylo uděleno oprávnění, díky vedlejším ustanovením vlastně kombinovaný (limity a omezení jimi stanovené lze chápat jako povinnosti při výkonu přiznaného oprávnění). Pravomoc formulovat vedlejší ustanovení musí být v zákoně stanovena výslovně. ${ }^{48}$ Doktrinálně lze diskutovat o tom, zda to má platit i pro koncesní režim, kde by snad bylo možno jejich stanovení opřít o obdobné důvody, o jaké lze opřít zamítnutí žádosti.

Řešení, které počítá s udělením oprávnění tacite, je u povolovacích režimů problematické a přinejmenším by mělo být „,kompenzováno“ možností dodatečného stanovení jinak obligatorně ukládaných vedlejších ustanovení.

Procesním standardem je u povolovacích režimů správní řízení (vzniku hmotněprávního vztahu tak předchází procesní vztah). Kvalifikovaně dotčené třetí osoby mají postavení účastníkủ ř́zení.

Dosud uvedené režimy týkající se přiznávání oprávnění byly iniciovány adresátem veřejné správy. Režim přiznání oprávnění z moci úřední pamatuje na možnost, popřípadě povinnost přiznat adresátovi určité veřejné subjektivní právo ex officio. Uplatnění tohoto režimu je výjimečné. ${ }^{49}$

\subsection{K REŽIMƯM TÝKAJÍCÍM SE UKLÁDÁNÍ POVINNOSTÍ}

Schéma základních režimů ukládání povinností lze popsat jako čtyřrozměrné až pětirozměrné.

V prvé řadě je založeno na tom, zda je daná povinnost uložena neurčitému okruhu adresátů (neadresné režimy), nebo konkrétním adresátům (adresné režimy).

Daná povinnost může vzniknout ze zákona, nebo z projevu vůle př́ílušného vykonavatele veřejné správy. U neadresných režimů vzniká povinnost bud' př́mo ze zákona, tedy ex lege (s tím, že může být konkretizována prováděcím právním předpisem), popř́padě i z obecně závazné vyhlášky (př́ímý neadresný režim), nebo z opatření obecné povahy, tedy ex actu (zprostředkovaný neadresný režim). U adresných režimů to je vždy ex actu (formou správního aktu, nebo faktického pokynu, popřípadě bezprostředního zásahu), adresný režim je tedy vždy zprostředkovaný.

Členění těchto režimů závisí rovněž na tom, zda je povinnost formulována pozitivně jako př́ikaz (pozitivní režim), nebo negativně jako zákaz (negativní režim); vzhledem $\mathrm{k}$ možnosti formulovat některá pravidla dvojím způsobem je toto členění relativní.

U adresných režimů a zprostředkovaných neadresných režimů má význam rozlišovat, zda je povinnost ukládána obligatorně a zda má obligatorní (nebo fakultativní) obsah, nebo zda je ukládána fakultativně a zda má fakultativní (popř́padě obligatorní) obsah, s ohledem na tyto poslední dva parametry lze režimy členit na obligatorní/fakultativní co do uložení/obsahu povinnosti (čtyři kombinace). V př́padě fakultativních režimů jde ještě o podobu diskrece, jíž je vybaven př́slušný vykonavatel veřejné správy (volba z několika mála alternativ vs. volba $\mathrm{v}$ rámci spojitého intervalu).

48 Viz např. rozsudek Nejvyššího správního soudu ze dne 9. prosince 2009, č. j. 1 As 67/2009-64.

$49 \mathrm{Na}$ takovou situaci pamatuje cit. správní rád [viz jeho § 27 odst. 1 písm. b)]. Svérázným hmotněprávním základem může být v př́ípadě nového rozhodnutí ve prospěch adresáta ustanovení § 101 písm. c) cit. správního řádu. 
Specifickým případem adresného pozitivního režimu je uložení povinnosti adresáta iniciovat reaktivní, schvalovací nebo povolovací režim. ${ }^{50}$

Svéráznou a do značné míry odlišnou ${ }^{51}$ podskupinu představují režimy založené na dobrovolném převzetí povinnosti (recepční). Může jít o převzetí formou jednostranného prohlášení adresáta (deklarativní režim). Subjektem povinnosti se adresát může stát zveřejněním prohlášení, popř́padě uplynutím určité doby od zveřejnění, dojitím prohlášení př́islušnému vykonavateli veřejné správy nebo na prohlášení reagujícím úkonem př́islušného vykonavatele veřejné správy. Výjimečně může jít o podání (a schválení) žádosti. ${ }^{52}$ Inverzní situací je jednostranné odmítnutí výkonu povinnosti. ${ }^{53}$

Do rodiny „povinnostních“ režimů patří i nejtypičtější nadstavbové (sekundární) režimy.

Za prvé to je dozorčí režim. Ten spočívá $\mathrm{v}$ úřední kontrole dodržování právních povinností. $V$ jeho rámci př́íslušný vykonavatel veřejné správy sleduje a hodnotí chování dozorovaného. Dozorčí vztahy se uplatňují při výkonu správního dozoru, v rámci státního dozoru nad nestátními nositeli veřejné správy i v rámci vnitřních organizačních/ rrídících vztahů veřejné správy. ${ }^{54}$ Vedle hmotněprávního vztahu zde existuje i vztah procesní. ${ }^{55} \mathrm{~V}$ návaznosti na negativní zjištění je tento režim pouze jakýmsi mezičlánkem, následně se uplatní ještě zejména některý ze sankčních režimů.

Za druhé to jsou sankční režimy. Rušiteli primární právní povinnosti vzniká sekundární povinnost strpět uloženou sankci. K porušení povinnosti může dojít jak ve vazbě na primární „povinnostní“ režim, tak ve vztahu k některému „oprávněnostnímu“ režimu. Jde jednak o nápravný (sankční) režim, jednak o správnětrestní (sankční) režim.

$\mathrm{V}$ př́ípadě nápravného režimu může povinnost zjednat nápravu, popřípadě povinnost kompenzovat způsobenou újmu vzniknout jak ex actu (bude založena formou správního aktu nebo faktického pokynu), tak ex lege.

V př́ípadě správnětrestního režimu vzniká hmotněprávní odpovědnostní vztah dříve než procesní vztah (spácháním správního deliktu) a vznik procesního vztahu (sdělením obvinění, popřípadě podáním návrhu na zahájení řízení ${ }^{56}$ je nutným předpokladem uplatnění odpovědnosti za správní delikt. Až na ojedinělé výjimky je uplatnění správnětrestního režimu iniciováno z moci úřední. Iniciace je zásadně obligatorní (princip legality), ${ }^{57}$ výjimečně fakultativní (princip oportunity). ${ }^{58}$ Uložení sankce (správního

50 Viz § 91d odst. 1 zákona č. 277/2009 Sb., o pojištovnictví, ve znění pozdějších předpisů (povinnost předložit ke schválení ozdravný plán).

51 Povinnost si „ukládá“ sám adresát veřejné správy. Alternativní konstrukcí by bylo považovat projev vůle adresáta za právní skutečnost, na níž závisí vznik oprávnění ex lege.

52 Viz $\S 4, \S 5$ a $\S 5$ a zákona č. 585/2004 Sb., o branné povinnosti a jejím zajišt’ování (branný zákon), ve znění pozdějších předpisů; jde o dobrovolné převzetí branné povinnosti (žádost o povolání do služebního poměru vojáka z povolání, žádost o zařazení do aktivní zálohy, žádost o účast na vojenském cvičení).

53 Viz $§ 6$ cit. branného zákona; odmítnout lze vykonávat mimořádnou službu z důvodu svědomí nebo náboženského vyznání.

${ }^{54} \mathrm{~S}$ tím, že v rámci vnitřních vztahů jde nejen o kontrolu dodržování právních povinností.

55 Kontrolní proces je upraven zákonem č. 255/2012 Sb., o kontrole (kontrolní řád), ve znění pozdějších předpisů, vưči němuž se subsidiárně použije cit. správní ŕád.

56 Viz $\$ 33$ odst. 1 zákona č. 85/1996 Sb., o advokacii, ve znění pozdějších předpisů.

57 Viz $\$ 78$ odst. 1 zákona č. 250/2016 Sb., o odpovědnosti za přestupky a řízení o nich.

58 Viz např. § 54a odst. 4 zákona č. 582/1991 Sb., o organizaci a provádění sociálního zabezpečení, ve znění pozdějš́ich předpisů, § 46e odst. 1 zákona č. 6/1993 Sb., o České národní bance, ve znění pozdějších 
trestu, ochranného opatření) je podmíněno vyslovením viny (autoritativním konstatováním odpovědnosti).

Sankční režimy se mohou uplatnit i bez návaznosti na dozorčí režim.

\subsection{K DALŠÍM NADSTAVBOVÝM REŽIMU゚M}

\section{kující.}

Některé nadstavbové režimy mohou být souhrnně označeny jako modifi-

První z nich je již zmíněný tichý režim. Jde o úpravu specifického hmotněprávního důsledku marného uplynutí lhůty pro uskutečnění úkonu vykonavatele veřejné správy v rámci reaktivních, schvalovacích nebo povolovacích režimů. Oprávnění bud' vznikne (pozitivní fikce/domněnka), nebo nevznikne (negativní fikce/domněnka). Průchodu tohoto režimu brání imperfektní podání adresáta. Pro př́ípad, že existence vady podání bude sporná, je vhodné zakotvit pravomoc určit, zda je podání vadné, či nikoli. Zvlášt' je třeba pamatovat na řešení situace, kdy oprávnění vznikne, aniž adresát splňoval všechny stanovené (hmotněprávní) předpoklady.

Další z této skupiny je režim exempční. Prostřednictvím udělené výjimky 59 je bud' prolomena určitá povinnost, resp. určité omezení, nebo rozšířena možnost přiznat určité oprávnění. Na udělení výjimky by zásadně neměl být právní nárok. Přinejmenším z obecných zásad právních se dovozuje požadavek ekvity udělování výjimek. Zákon může stanovit meze a/nebo hlediska pro udělování výjimek. ${ }^{60}$

Modifikující povahu má i remodelační režim, spočívající v zakotvení možnosti změny oprávnění či povinnosti. Tato změna může být dodatečná (po vzniku oprávnění/ povinnosti), nebo v rámci procesu, v němž se rozhoduje o vzniku oprávnění/povinnosti. Iniciovat ji může adresát nebo vykonavatel veřejné správy. Hodnotově může znamenat zlepšení, či zhoršení pozice adresáta. Remodelaci podobná je formulace obsahu právního vztahu související se zhojením nedostatku či vady projevu vůle ${ }^{61}$ (sanační režim).

Nadstavbovou povahu mají dále dispozitivní režimy, které obsahují náznaky/prvky dispozitivní správněprávní regulace. Prostý dispozitivní režim dovoluje participantům právních vztahů odchylné než předepsané/doporučené chování. Stanoví-li zákon objektivní důvody odchylného chování nebo objektivní okolnosti, za nichž je odchylné chování přípustné, jde o kvalifikovaný dispozitivní režim. Složitější je režim tzv. měkké regulace, jehož podstatou je presumpce dodržení požadavků stanovených obecnějšími závaznými pravidly za předpokladu dodržení požadavků/parametrů stanovených kon-

předpisů, nebo $\S 9$ odst. 5 zákona č. 395/2009 Sb., o významné tržní síle při prodeji zemědělských a potravinářských produktů a jejím zneužití, ve znění pozdějších předpisů. U hmotněprávních správních deliktů jde z doktrinálního hlediska o nežádoucí tendenci (může ovšem jít o nedocenění významu materiálního znaku přestupku). Další vývoj legislativy nelze spolehlivě předvídat.

59 Jde o nejrůznější situace. Viz např. $§ 169$ cit. stavebního zákona (výjimky z obecných požadavků na výstavbu), nebo $\S 88$ a $§ 156$ zákona č. 187/2006 Sb., o nemocenském pojištění, ve znění pozdějších předpisů (odstraňování tvrdosti).

60 Např. § 43 zákona č. 114/1992 Sb., o ochraně přírody a krajiny, ve znění pozdějších předpisů, o výjimkách ze zákazů ve zvláště chráněných územích.

61 Za zamyšlení stojí možnost ratihabice, konvalidace a/nebo konverze. Ke konverzi viz $§ 157$ cit. správního ř́du. 
krétnějšími nezávaznými (doporučujícími) pravidly. ${ }^{62}$ Nastoupivší právní domněnka může být, obecně vzato, jak nevyvratitelná, tak (za stanovených okolností) vyvratitelná.

Samostatnou skupinu nadstavbových režimů tvoří režimy týkající se řešení sporů (konfliktní režim) a/nebo odstraňování pochybností (určovací režim) ohledně existence vztahů správního práva či ohledně jejich parametrů. Jejich iniciace může př́slušet adresátovi veřejné správy, ${ }^{63}$ nebo (i) vykonavateli veřejné správy ${ }^{64}$. Procesní formou je správní řízení a meritorním výsledkem deklaratorní správní akt (u režimu iniciovaného adresátem též zamítnutí návrhu). Podobný režim se týká řešení rozporů v rámci státní správy. ${ }^{65}$ Smírné řešení sporu, resp. potenciálního sporu je smyslem mediace (mediační režim). ${ }^{66}$

\subsection{KE KOOPERAČNÍM REŽIMŮM}

Na rozdíl od jednostranných režimů předpokládají kooperační režimy souladnou aktivitu více stran.

Nejvyšší intenzitu kooperace vyžaduje smluvní režim, kde je předpokladem vzniku oprávnění/povinnosti shodný projev vůle dvou nebo více stran (uzavření veřejnoprávní smlouvy). ${ }^{67}$ Může jít o smlouvu mezi nositeli veřejné správy, o smlouvu mezi nositelem/vykonavatelem a adresátem veřejné správy, popř́padě o smlouvu mezi adresáty veřejné správy. Předpokladem účinnosti smlouvy může být následné úřední schválení (kombinace se schvalovacím režimem), nebo souhlas třetích osob. U elektivních veřejnoprávních smluv, kde smluvní režim substituuje povolovací režim, je žádoucí, aby smlouva měla bohatší obsah, než jaký má (může mít) správní akt, který je její alternativou. ${ }^{68}$ Požadavek konsensuálního prostředí formulovaný v rámci schvalovacího nebo jiného jednostranného režimu jako předpoklad udělení souhlasu nebo uskutečnění jiného úkonu vykonavatele veřejné správy nejspíš neindikuje existenci samostatného (svébytného) režimu úpravy, vyvolává však otázku, proč se v popsané situaci neuplatňuje smluvní režim. ${ }^{69}$

Nižší intenzita kooperace se předpokládá u režimu vyjadřujícího jinou formu součinnosti, např. pouhé projednání (negociační režim).

V rámci státní správy je formou kooperace rovněž subsumpce závazného stanovis$\mathrm{ka}^{70}$ vydaného tzv. dotčeným orgánem (režim subsumpce).

62 Viz § 4a zákona č. 22/1997 Sb., o technických požadavcích na výrobky, ve znění pozdějších předpisů; jde o problematiku harmonizovaných a uznaných technických norem.

63 Viz $§ 141$ a $§ 142$ cit. správního řádu.

64 Např. $\S 3$ odst. 3 zákona č. 44/1988 Sb., o ochraně a využití nerostného bohatství (horní zákon), nebo § 3 odst. 3 zákona č. 289/1995 Sb., o lesích a o změně a doplnění některých zákonů (lesní zákon).

65 Viz $§ 136$ odst. 6 cit. správního řádu.

66 Viz § 20d a násl. zákona č. 634/1992 Sb., o ochraně spotřebitele, ve znění pozdějších předpisů; jde o smírné řešení spotřebitelských sporů.

67 Obecně viz $§ 159$ a násl. cit. správního řádu.

68 Př́ikladem elektivní veřejnoprávní smlouvy je smlouva nahrazující některá územní rozhodnutí (§ 78a cit. stavebního zákona) nebo smlouva nahrazující stavební povolení (§ 116 téhož). Ke škodě věci tyto smlouvy uvedený požadavek nesplňují.

69 Ve vztahu $\mathrm{k}$ výše uvedeným př́kladům by šlo o veřejnoprávní smlouvu namísto územního souhlasu a o veřejnoprávní smlouvu namísto souhlasu s ohlášením stavebnímu úřadu.

70 „Nesamostatného“ správního aktu. Procesní stránku řeší § 149 cit. správního řádu. 
Alternativou kooperace $\mathrm{v}$ rámci státní správy je integrace působnosti (integrační režim).

\subsection{K REŽIMƯM VÝKONU PUீSOBNOSTI A PRAVOMOCI}

menším

Z hlediska výkonu působnosti a pravomocí se nabízí vymezit přinej-

- kategorický režim, jehož uplatnění jednoznačně determinuje výsledek (je výrazem plné vázanosti správy),

- interpretační režim, kde výsledek závisí na výkladu neurčitého právního pojmu,

- vyvažovací režim, kde výsledek závisí na volném hodnocení podkladů, při němž př́islušný vykonavatel veřejné správy poměřuje zákonná hlediska ochrany různých veřejných zájmů (různých aspektů veřejného zájmu), či zájem veřejný a zájmy soukromé, popř́ípadě (jestliže to je významné pro ochranu veřejného zájmu) soukromé zájmy navzájem, ${ }^{71}$

- diskreční režim, který je výrazem uplatnění správního uvážení,

- participační režimy, kdy se na výkonu působnosti a pravomoci podílí více vykonavatelů veřejné správy (může jít i o některý z režimů kooperačních) ${ }^{72}$

\subsection{K REŽIMŮM URČUJÍCIM HRANICE SPRÁVNĚPRÁVNÍ REGULACE}

Vnitřní hranici správněprávní regulace představuje rozhraní mezi externem a internem veřejné správy. Od vztahů vznikajících při výkonu veřejné správy, které mají, resp. musí mít kvalitu právních vztahů (vztahů správního práva), se odlišují vztahy $\mathrm{v}$ rámci organizace veřejné správy, u nichž tomu tak není. ${ }^{73}$ Typicky jde o vztahy nadř́izenosti a podřízenosti. S vytvářením organizačních struktur veřejné správy založených na vztazích nadřízenosti a podřízenosti souvisí organizační režim. ${ }^{74} \mathrm{O}$ vztahy nadřízenosti a podřízenosti jde i při delegaci státní správy na jiné osoby (delegační režim).

Vnější hranici správněprávní regulace představuje rozmezí s trestněprávní regulací a rozmezí se soukromoprávní regulací. První z nich souvisí s vymezením již zmíněného správnětrestního režimu. Ve vztahu k druhému lze uvést, že správní právo vytváŕí zejména při úpravě tzv. jiné veřejné správy prostor/rámec pro plnění jejích úkolů soukromoprávními prostředky ${ }^{75}$ (zcivilňující režim). V souvislosti s povoláváním osob soukromého práva $\mathrm{k}$ plnění úkolů tzv. jiné správy se uplatňuje jednostranný autorizační režim (autorizace formou správního aktu), popř́ípadě dvoustranný autorizační režim (jako specifický kooperační režim = autorizace formou veřejnoprávní smlouvy). Kromě toho správní právo rovněž podrobuje některé soukromoprávní vztahy dozorčímu režimu a správnětrestnímu režimu.

71 Obecně vzato může jít jak o př́pad jejich konkurence/střetu, tak o př́ípad jejich synergie.

72 Srov. u již zmíněných závazných stanovisek.

73 Kvalita právních vztahů jim ovšem může být zákonem „propůjčena“.

74 Srov. zejména plnění úkolů veřejné správy prostřednictvím příspěvkových organizací zřizovaných státem nebo územními samosprávnými celky.

75 Např. § 117 cit. stavebního zákona (posuzování stavebního záměru autorizovaným inspektorem). 
Specifické je rozhraní národní právní regulace a evropské právní regulace. Požadavky evropského práva vyvolaly potřebu internacionalizovaných režimů, u nichž v souvislosti s přiznáváním oprávnění nebo s ukládáním povinností naší národní autoritou (českým vykonavatelem veřejné správy) hrají určitou roli i jiní vykonavatelé, jimiž jsou př́slušné autority členských států a/nebo př́slušná evropská autorita. ${ }^{76}$

\section{REŽIMY A OBECNÉ FIGURY SPRÁVNÍHO PRÁVA}

Uplatnění řady režimů či jejich kombinace typicky „vyústuje“ v tzv. obecné figury správního práva.

Obecnou figurou správního práva se zde rozumí spletenec norem správního práva tmelený potřebou/snahou řešit určitou idealizovanou, na věcné povaze nezávislou, resp. od věcných souvislostí oproštěnou situaci reálného světa/života. ${ }^{77}$ Připomíná-li vymezení „právní figury“ vymezení „právního institutu“, jde o podobnost nikoli náhodnou (termín „figura“ má v traktované souvislosti zejména podtrhnout skutečnost, že nejde o konkrétní věcný význam). ${ }^{78}$

V návaznosti na základní režimy týkající se přiznávání oprávnění lze „čitelné“ obecné figury formulovat u registračního módu reaktivních režimů (pozitivním výsledkem, tedy figurou, je registrace), u schvalovacích režimů (figurou je souhlas), u klasického módu povolovacích režimů (figurou je povolení) nebo u koncesního módu povolovacích režimů (figurou je koncese).

U dalších režimů týkajících se přiznávání oprávnění by bylo obtížné čitelně obecné figury formulovat. Tak v rámci volného režimu by obecnou figurou mohla být ,volnost“ coby výraz principu legální licence. Spolehlivějš̌́ figury v návaznosti na volný režim lze vymezit až při jisté konkretizaci věcné náplně oprávnění (kdy již nejde o obecnou figuru správního práva „vůbec“, tedy ve smyslu výše naznačeném). Takovou figurou by bylo obecné uživání veřejně přístupných statků. Podobně by u oznamovacích režimů šlo o „podmíněnou volnost“, nebot' oznamovací režim lze označit i jako podmíněně volný (volnost je podmíněna oznámením).

Nejtypičtějšími obecnými figurami navazujícími na režimy ukládání povinností jsou př́íkaz a zákaz (pro neadresné i adresné režimy), popřípadě pokyn (pro adresné zprostředkované režimy).

76 Př́́kladem jsou ustanovení § 11 odst. 3 , § 17 odst. $1, \S 61$ odst. $3, \S 91, \S 179$ odst. 3 a $\S 180$ a násl. zákona č. 374/2015 Sb., o ozdravných postupech a řešení krize na finančním trhu, ve znění pozdějších předpisů. Jiným př́kladem jsou ustanovení § 17 a násl. zákona č. 90/2016 Sb., o posuzování shody stanovených výrobků při jejich dodávání na trh (problematika tzv. oznámených subjektů).

77 Na rozdíl od speciálních figur, popřípadě speciálních figur různého stupně speciality, které přinejmenším k některým věcným souvislostem přihlížejí.

78 V české právní terminologii se pojem ,„právní figura“ (či „právnická figura“) prakticky nevyskytuje. Naproti tomu v německé právní terminologii lze pojem ,,Rechtsfigur “ považovat za synonymum pojmu „Rechtsinstitut". 
V návaznosti na některé další režimy se prozatím (namátkou) rýsují alespoň tyto obecné figury správního práva:

- (správní) dozor (v návaznosti na dozorčí režim),

- (správní) nápravné opatření (v návaznosti na nápravný režim),

- (správní) trest, (správní) ochranné opatření (v návaznosti na správnětrestní režim),

- tichý souhlas (v návaznosti na tichý režim),

- (správní) spor, (správní) určení a (správní) mediace (v návaznosti na konfliktní režim, určovací režim a mediační režim),

- veřejnoprávní smlouva a veřejnoprávní ujednání, popř́ípadě subsumpce (v návaznosti na kooperační režimy),

- autorizace (v návaznosti na autorizační režim).

Vzhledem k potřebě „odladit“ výchozí prístup a s ohledem na možný rozsah tohoto př́spěvku budiž podrobnější pojednání o figurách správního práva a o jejich systematice, resp. o př́stupu k jejich systemizaci ponecháno na pozdější dobu.

$$
* * *
$$

Správní právo je př́značné tím, že se týká v podstatě všech oblastí/stránek života společnosti. To je hlavní př́činou roztříšsěnosti pramenů jeho hmotněprávní materie. Nepřehlednost úprav je dána (nejen) i tradičním legislativním polycentrismem. ${ }^{79}$

Shodné nebo podobné právní konstrukce jsou v pozitivním právu často formulovány značně odlišně. Legislativní praxi (tvorbě zákonů a jiných právních předpisů) i interpretační praxi podmiňující aplikaci práva (rozhodování jednotlivých př́ípadů) může přispět poodhalení „společného“, důsledkem formulační rozvolněnosti na první pohled „neviditelného“.

Uvedený př́istup ke zkoumání správního práva je jistě třeba podrobit revizi/verifikaci. Obstojí-li, může rovněž přispět k plastičtější doktrinální charakteristice tohoto důležitého segmentu (nejen našeho) právního řádu. Dlužno (sebe)kriticky připustit, že se teorii dosud nedaří, snad s jistou výjimkou týkající se správní činnosti a jejích forem, hmotné správní právo komplexně rozebrat/zanalyzovat a systematicky uspořádat.

S jistou dávkou neskromnosti si lze ještě dovolit uvést, že naznačený př́stup může vést k poznání, že správní právo je o něco jednodušší, než se zdá. Nestane-li se tak, zůstane alespoň pokus uspořádat reálie hmotného správního práva „trochu jinak“ než obvykle.

JUDr. Ing. Josef Staša, CSc.

Právnická fakulta Univerzity Karlovy

stasa@prf.cuni.cz

79 Srov. § 24 zákona č. 2/1969 Sb., o zřízení ministerstev a jiných ústředních orgánů státní správy České republiky, ve znění pozdějších předpisů. Požadované tempo legislativního procesu a množství předkládaných návrhů přitom znesnadňuje, až znemožňuje žádoucí/potřebnou koordinaci na úrovni vlády. Domácí právní jazyk bývá mnohdy zbytečně/nadbytečně deformován transpozičními snahami. Nezávisle na tom rušivě působí některé poslanecké návrhy zákonů a zejména neorganické pozměňovací návrhy v parlamentních fázích legislativního procesu. 